\title{
PRAKTIKALITAS MODUL MEDIA PEMBELAJARAN BIOLOGI BERBASIS PROJECT BASED LEARNING (PjBL)
}

\author{
Diana Susanti, Vivi Fitriani, Liza Yulia Sari \\ Prodi Pendidikan Biologi, STKIP PGRI Sumatera Barat, Jalan Gunung Pangilun Padang \\ *Korespondensi Author: dianasusantimpd@yahoo.co.id
}

\section{INFO ARTIKEL}

\section{Histori Artikel}

Received 12 Desember 2019

Revised 10 Januari 2020

Accepted 14 Januari 2020

Published 23 Januari 2020

Keywords:

Module, Project Based Learning, Practicality

\begin{abstract}
ABSTRAK
Media pembelajaran biologi mengajarkan mahasiswa untuk menciptakan media di SMP/SMA. Dalam pelaksanaan perkuliahan media yang diciptakan mahasiswa banyak yang tidak sesuai dengan tujuan pembelajaran, selain itu bahan ajar yang tersedia untuk membantu mahasiswa dalam menciptakan media biologi SMP/SMA tersebut belum memadai. Maka dikembangkan modul media pembelajaran biologi berorientasi Project Based Learning (PjBL). Pengembangan modul tersebut telah dilakukan sampai tahap validitas dengan hasil sangat valid. Tujuan dari penelitian ini adalah melihat hasil praktikalitas modul media pembelajaran biologi berbasis project based learning (pjBL). Penelitian ini merupakan penelitain pengembangan menggunakan model pengembangan 4-D yang terdiri atas 4 tahap yaitu define, design, develop, and disseminate. Pada penelitian ini hanya tahap develop yaitu uji praktikalitas. Data penelitian diperoleh dari angket praktikalitas yang diberikan pada dosen dan mahasiswa dan diolah dengan analisis deskriptif. Hasil praktikalitas oleh dosen memperoleh rerata $96,17 \%$ (sangat praktis) dan rerata mahasiswa $81,90 \%$ (sangat praktis). Kesimpulan dari penelitian ini adalah dihasilkan modul media pembelajaran biologi berorientasi Project Based Learning (PjBL) sangat praktis dari dosen dan mahasiswa.
\end{abstract}

\section{ABSTRACT}

Biology learning media teaches students to create media in middle/high school. In the implementation of media lectures created by students, many are not by following the learning objectives, in addition to the teaching materials available to help students in creating the middle/high school biology media are inadequate. Then the biology learning media module was developed based on Project Based Learning (PjBL). The module development has been carried out until the validity stage with very valid results. The purpose of this study is to see the results of the practicality of biology learning media module project-based learning (PjBL). This research is a research development using a 4-D development model consisting of 4 stages namely define, design, develop, and disseminate. In this research, only the developing stage is the practicality test. The research data were obtained from the practicality questionnaire given to lecturers and students and were processed with descriptive analysis. The practicality results obtained by the lecturer averaged $96.17 \%$ (very practical) and the average student $81.90 \%$ (very practical). This research concludes that a biology-based module of project-based learning ( $\mathrm{PjBL}$ ) oriented learning media is produced from lecturers and students.

Copyright (C) 2019 Universitas Negeri Medan. Artikel Open Access dibawah lisensi CCBY-4.0 (https://creativecommons.org/licenses/by/4.0) 


\section{How To Cite:}

Susanti, D., Fitriani, V., \& Sari, L.Y. (2019). Praktikalitas Modul Media Pembelajaran Biologi Berbasis Project Based Learning (PjBJ) . Jurnal Pelita Pendidikan, 7(4), 139-143.

\section{PENDAHULUAN}

Matakuliah media pembelajaran biologi membahas pemahaman tentang pengertian, jenis, karakteristik dan fungsi media dalam komunikasi umumnya dan pembelajaran biologi khususnya, serta menentukan dan merancang media pembelajaran yang sesuai dengan karakteristik materi dan tujuan pembelajaran, mengoperasionalkan media pembelajaran biologi SMP dan SMA di dalam kelas. Perkuliahan ini memberikan bekal kepada mahasiswa untuk belajar membuat, merancang dan menciptakan media pembelajaran biologi dengan memanfaatkan berbagai jenis alat/bahan dan kemajuan IT. Matakuliah ini tidak memiliki kegiatan praktikum, kegiatan perkuliahan hanya tatap muka. Setiap pembuatan media pembelajaran dilakukan diluar kegiatan tatap muka dan hanya sebatas tugas rumah. Permasalahan yang terjadi selama ini, masih banyak mahasiswa yang kurang kreatif dalam menciptakan/merancang media, bahkan media yang dibuat dan dihasilkan saat perkuliahan terkadang tidak sesuai dengan tujuan pembelajaran yang telah ditentukan. Misalkan dari segi bentuk dan warna yang mereka buat dari media tersebut tidak sesuai dengan warna aslinya.

Selain itu, mereka juga kurang terampil dalam menciptakan media yang berbasis teknologi komputer seperti power point dan video.Kondisi lain yang menyebabkan kurangnya kreatifitas mahasiswa dalam perkuliahan adalah tidak tersedianya bahan ajar yang mendukung mereka dalam memahami konsep media pembelajaran serta merancang/menciptakan berbagai jenis media. Kurangnya pemahaman mahasiswa dalam memahami konsep dan materi yang telah diberikan dosen karena mahasiswa hanya mengandalkan bahan ajar berupa power point untuk dibaca saat perkuliahan tanpa dibantu bahan ajar lainnya. Bahan ajar yang digunakan dosen selama ini hanya membantu pemahaman konsep dari berbagai media, bukan dalam merancang/menciptakan media yang kreatif yang digunakan dalam pembelajaran akibatnya dalam pembuatan media, mereka kurang terampil dan nilai keterampilan dalam menciptakan media menjadi rendah. Pengembangan modul media pembelajaran biologi ini berbasis Project Based Learning (PjBL) telah dikembangkan sampai tahap validitas. Hasil analisis kebutuhan akan modul menunjukkan kalau modul untuk perkuliahan media pembelajaran biologi sangat dibutuhkan. Dari hasil tersebut terlihat bahwa bahan ajar yang digunakan oleh mahasiswa untuk menciptakan,merancang dan membuat media pembelajaran biologi SMA/SMP belum tersedia. Sehingga mahasiswa sangat membutuhkan bahan ajar demi mewujudkan keinginan mereka tersebut.

Sedangkan hasil validitas dari modul yang telah dirancang, dikategorikan sangat valid oleh para pakar materi, bahasa, stategi dan media. Para pakar mengatakan kalau modul yang telah di design telah sesuai baik dengan kurikulum, kebutuhan mahasiswa, kegrafisan dan kebahasaan modul. Untuk itu pengembangan modul berbasis projectbased learning dilanjutkan ketahap develop khususnya praktikalitas baik dari dosen maupun mahasiswa.

Modul yang dikembangkan berbasis projectbased learning. PjBI ini dilpilih Karena PjBL mampu menggiring mahasiswa merancang, menciptakan serta membuat suatu produk dengan instruksi yang benar. Menurut Thomas (2000) Project based learning adalah model pembelajaran yang mengorganisasi kelas dalam sebuah proyek. Addiin (2014) juga menyatakan bahwa, PjBL ini membuat proyek-proyek yang menghendaki mahasiswa untuk, memecahkan masalah nyata dan isu-isu yang memiliki kepentingan untuk orang lain, secara aktif terlibat dalam pembelajaran mereka dan memilih hal-hal penting selama projek, menunjukkan secara nyata bahwa mereka telah belajar konsep-konsep kunci dan keterampilan. PjBI ini diharapkan dapat meningkatkan motivasi belajar mahasiswa, meningkatkan kemampuan dan 
kreativitas mahasiswa untuk membuat proyek (media pembelajaran biologi), meningkatkan kolaboratif atau peran kerjasama kelompok, dan mengembangkan kemampuan merencanakan. Tujuan dari penelitian ini adalah menghasilkan modul media pembelajaran biologi berorientasi Project based learning yang praktis.

\section{METODE PENELITIAN}

Penelitian ini merupakan penelitian pengembangan dengan menggunakan model 4D. Melalui 4 tahap pengembangan yaitu define, design, develop and disseminate. Penelitian dilakukan di tahap develop yaitu melihat hasil praktikalitas penuntun praktikum yang dikembangkan baik dari dosen maupun mahasiswa sebagai pengguna. Penelitian memanfaatkan angket sebagai instrument untuk mengumpulkan data dengan 4 pilihan jawaban yaitu sangat setuju, setuju, kurang setuju dan tidak setuju. Angket diberikan kepada 3 orang dosen dan 61 orang mahasiswa Angket dimodifikasi dari Susanti (2019)

\section{HASIL DAN PEMBAHASAN}

Data praktikalitas modul media pembelajaran biologi diperoleh dari pengisian angket oleh 3 orang dosen dan 61 orang mahasiswa. Praktikalitas pada dosen dan mahasiswa dilihat dari 4 variabel, yaitu kemudahan penggunaan modul, waktu yang diperlukan dalam pelaksanaan, kemudahan dalam mengiterprestasikan, serta memiliki ekivalen yang sama. Masing-masing variabel terdiri dari beberapa indikator, seperti mahasiswa menyimpan modul dengan mudah, modul mudah digunakan sendiri dengan aspek yang diamati kemudahan dalam penggunaan, meliputi: mudah, diatur, disimpan dan dapat digunakan sewaktu-waktu, waktu yang diperlukan dalam pelaksanaan sebaiknya sangat singkat, cepat dan tepat, mudah diinterpretasikan oleh dosen ahli maupun dosen lain, dan memiliki ekivalensi yang sama, sehingga bisa digunakan sebagai pengganti atau variasi. Analisis praktikalitas ini diolah dengan menggunakan rumus modifikasi dari Riduwan dan Kuncoro (2011).

$$
\text { Nilai praktikalitas }=\frac{\text { Skor rata }- \text { rata }}{\text { Skor maksimum }}
$$

$x 100 \%$

Penilaian praktikalitas menggunakan kriteria dari

Riduwan (2010) yang dimodifikasi.

Tabel 1. Kriteria Kebutuhan modul

\begin{tabular}{c|c}
\hline Tingkat Pencapaian (\%) & Kriteria Aktivitas \\
\hline $81-100$ & Sangat praktis \\
\hline $61-80$ & Praktis \\
\hline $41-60$ & Cukup praktis \\
\hline $21-40$ & Tidak praktis \\
\hline $1-20$ & Sangat tidak praktis \\
\hline
\end{tabular}

oleh mahasiswa, petunjuk penggunaan modul membantu mahasiswa dalam mnggunakan media, penggunaan modul sesuai dengan waktu yang tersedia, mudah dienterprestasikan oleh mahasiswa, serta modul memiliki ekivalensi yang sama dengan bahan ajar yang lain. Hasil penilaian praktikalitas oleh dosen memperoleh rerata $96,17 \%$ (sangat praktis), dan hasil penilaian praktikalitas oleh mahasiswa juga diperoleh rerata 81,03\%.(sangat praktis).Hasil Praktikalitas modul media pembelajaran biologi oleh dosen pada tabel berikut.

Tabel 1. Hasil Praktikalitas modul media pembejaran biologi oleh Dosen

\begin{tabular}{cllccc}
\hline No & Variabel Praktikalitas & \multicolumn{1}{c}{ Indikator } & Nilai (\%) & Keterangan \\
\hline 1. & $\begin{array}{l}\text { Kemudahan penggunaan } \\
\text { modul }\end{array}$ & $\begin{array}{l}\text { Kemudahan modul saat pelaksanaan } \\
\text { pembelajaran; Modul mudah digunakan } \\
\text { oleh dosen }\end{array}$ & 95,23 & Sangat Praktis \\
\hline 2. & $\begin{array}{l}\text { Waktu yang diperlukan } \\
\text { dalam pelaksanaan }\end{array}$ & $\begin{array}{l}\text { Waktu yang disediakan dalam } \\
\text { menggunakan modul }\end{array}$ & 93,33 & Sangat Praktis \\
\hline 3. & $\begin{array}{l}\text { Kemudahan dalam } \\
\text { menginterprestasikan }\end{array}$ & $\begin{array}{l}\text { Mudah diinterprsetasikan oleh dosen ahli } \\
\text { maupun oleh dosen bidang studi biologi }\end{array}$ & 98,33 & Sangat Praktis \\
\hline 4. & $\begin{array}{l}\text { Memiliki ekivalen yang } \\
\text { sama }\end{array}$ & $\begin{array}{l}\text { Memiliki ekivalensi yang sama dengan } \\
\text { bahan ajar yang lain }\end{array}$ & 97,77 & Sangat Praktis \\
\hline \multicolumn{2}{l}{ Rata-rata } \\
\hline
\end{tabular}


Sedangkan hasil praktikalitas dari mahasiswa dapat dilihat pada tabel berikut.

Tabel 2. Hasil Praktikalitas modul media pembejaran biologi oleh Mahasiswa

\begin{tabular}{|c|c|c|c|c|}
\hline No. & $\begin{array}{c}\text { Variabel } \\
\text { Praktikalitas }\end{array}$ & Indikator & Nilai(\%) & Keterangan \\
\hline 1. & $\begin{array}{l}\text { Kemudahan } \\
\text { penggunaan } \\
\text { modul }\end{array}$ & $\begin{array}{l}\text { 1. Mahasiswa dapat menyimpan modul yang } \\
\text { mudah } \\
\text { 2. Modul mudah digunakan sendiri oleh } \\
\text { mahasiswa } \\
\text { 3. Petunjuk penggunaan modul membantu } \\
\text { mahasiswa dalam menggunakan media }\end{array}$ & 78,89 & Praktis \\
\hline 2. & $\begin{array}{l}\text { Waktu yang } \\
\text { diperlukan dalam } \\
\text { pelaksanaan }\end{array}$ & $\begin{array}{l}\text { Penggunaan modul sesuai dengan waktu yang } \\
\text { tersedia }\end{array}$ & 79,84 & Praktis \\
\hline 3. & $\begin{array}{l}\text { Kemudahan dalam } \\
\text { menginterprestasi } \\
\text { kan }\end{array}$ & Mudah diinterprsetasikan oleh mahasiswa & 83,19 & Sangat Praktis \\
\hline \multirow[t]{2}{*}{4.} & $\begin{array}{l}\text { Memiliki ekivalen } \\
\text { yang sama }\end{array}$ & $\begin{array}{l}\text { Modul memiliki ekivalensi yang sama dengan } \\
\text { bahan ajar yang lain }\end{array}$ & 82,21 & Sangat Praktis \\
\hline & & Rata-rata & 81.03 & Sangat Praktis \\
\hline
\end{tabular}

Praktikalitas media pembelajaran biologi yang dihasilkan pada modul media pembelajaran biologi yang telah dilakukan terhadap dosen dan mahasiswa didapatkan hasilnya yaitu, praktikalitas oleh dosen $96,17 \%$ (sangat praktis), begitu juga hasil angket yang diperoleh dari mahasiswa didapatkan hasil $81,03 \%$ (sangat praktis), artinya bahwa modul media pembelajaran biologi yang dihasilkan memberi kemudahan kepada dosen dan mahasiswa saat proses pembelajaran dan modul mudah digunakan. Dengan adanya modul dapat membantu dosen dan mahasiswa dalam menginterprestasikannya, serta memiliki ekivalensi yang sama dengan bahan ajar yang lain. Selain itu Siraj (2010: 4) juga mengatakan modul sangat efektif digunakan dalam belajar mahasiswa yang memiliki gaya belajar visual, aktif, dan reflektifSejalan juga dengan Kiong (2011: 1) menggunakan modul merupakan alternatif pendekatan siswa dalam pemecahan permasalahan belajar siswa. Sehingga modul dapat menjadi praktis baik oleh dosen maupun mahasiswa. Zaini dan Asnida (2015:138) bahwa kepraktisan perangkat pembelajaran telah tercapai apabila guru mampu menggunakan perangkat pembelajaran dan sebagian besar siswa memberikan respon positif. Hal ini sejalan dengan pendapat Plomp dan Nieveen (2007:27) bahwa suatu produk dapat dikatakan praktis apabila produk tersebut realistis dapat digunakan.
Dari empat variabel praktikalitas pada angket yang diisi oleh 3 orang dosen didapatkan persentase tertinggi yaitu pada variabel yang ke tiga yaitu kemudahan dalam menginterprestasikan, yang terdiri dari satu indikator yaitu mudah diinterprestasikan oleh dosen ahli maupun oleh dosen bidang studi biologi lainnya yaitu dengan persentase $98,33 \%$. Ini menandakan bahwa modul media pembelajaran biologi yang dihasilkan dapat membantu dosen dalam perkuliahan. Pada angket praktikalitas yang telah diisi oleh 61 orang mahasiswa juga didapatkan perentase tertinggi pada variabel yang ke tiga yaitu $83,19 \%$. Rahmadi (2015: 143) menjelaskan bahwa jika presentase keterlaksanaan pembelajaran setiap pertemuan di atas atau sama dengan $80 \%$, berarti produk yang dikembangkan praktis digunakan dalam pembelajaran. Modul media pembelajaran biologi yang dihasilkan berbasis PjBL. Menurut Aisyi et al (2013) Project-Based Learning (PjBL) memiliki langkah yang mudah dipahami oleh dosen dan mahasiswa karena memiliki langkah/sintak yang jelas. Seperti yang diungkapkan oleh Mahendra (2016) bahwa sintaks Project Base Learning (PjBL) terdiri dari, Penentuan Pertanyaan Mendasar (Start With the Essential Question), Mendesain Perencanaan Proyek (Design a Plan for the Project), Menyusun Jadwal (Create a Schedule), Memonitor peserta didik dan kemajuan proyek (Monitor the Students and the Progress of the Project), Menguji 
Hasil (Assess the Outcome), Mengevaluasi Pengalaman (Evaluate the Experience). Pembelajaran berbasis proyek merupakan model pembelajaran yang bertujuan untuk mendorong siswa untuk memecahkan masalah nyata dan mampu menghasilkan produk untuk menyelesaikan masalah tersebut. Selain itu menurut Yance (20313) PjBL mempunyai pengaruh yang berarti terhadap hasil belajar mahasisiwa baik pada ranah kognitif, afektif, dan psikomotor.

\section{KESIMPULAN}

Berdasarkan penelitian yang telah dilakukan dapat disimpulkan bahwa dihasilkannya modul media pembelajaran biologi berorientasi Project based learning yang sangat praktis baik dari dosen maupun mahasiswa.

\section{UCAPAN TERIMAKASIH}

Terimakasih kami ucapkan kepada DRPM DIKTI yang telah membiayai penelitian ini sepenuhnya.

\section{DAFTAR PUTAKA}

Aisyi, F.K., Elvyanti, S., Gunawan, T., \& Mulyana, E. 2013. Pengembangan Bahan Ajar TIK SMP Mengacu pada Pembelajaran Berbasis Proyek. Invotec. Vol.IX. (2):117- 128

Kiong, T.T, Yunos, J.B.M., Mohammad, B.B. 2011. The Development and Evaluation of The Qualitis Of Buzan Mid Mapping Module. Procedia - Social and Behavioral Sciences. Universiti Tun Hussein Onn Malaysia

Mahendra, I Wayan E. 2016."Project Based Learning Bermuatan Etnomatematika dalam Pembelajar Matematika".Jurnal Pendidikan Indonesia.ISSN:2541-7207.

Plomp, T. and N. Nieveen. 2007. An Introduction to Educational Design Research. Proceedings of The Seminar Conducted at The East China Normal University, Shanghai (PR China) November 23-26, 2007. 1-26.Of Guided Inquiry Teaching

Rahmadi, F. 2015. Pengembangan Perangkat Pembelajaran Berbasis Pemecahan Masalah Berorientasi pada Kemampuan Penalaran dan Komunikasi Mahasiswa. Pythagoras. 10(2):137145.

Thomas, J.W. (2000). A Review of Research on Project Based Learning. California : The Autodesk Foundation.
Susanti, D., Sari, L.Y., Fitriani, V. 2019. The using of handbook PBL oriented in introductory and laboratory techniques course. IOP Conf. Series: Journal of Physics: Conf. Series 1157 (2019) 022087. doi:10.1088/17426596/1157/2/022087

Yance, RD. 2013. Pengaruh Penerapan model Project Based learning terhadap Hasil Belajar Fisika. Pillar of Physics Education.

Zaini, M. dan Asnida, D. J. 2015. Pengembangan Perangkat IPA Biologi Berorientasi Hutan Mangrove untuk Siswa SMP. Seiiminar Nasional XII Pendidikan Biologi UNS. 134141. Method On Students Achievement In Logic. The International. 